\title{
PENGARUH PENGETAHUAN KEWIRAUSAHAAN, MOTIVASI BERUSAHA DAN KEMANDIRIAN USAHA TERHADAP KINERJA PEDAGANG KAKILIMA DI WILAYAH KOTAGEDE YOGYAKARTA
}

\author{
Ani Muttaqiyathun
}

Universitas Ahmad Dahlan

animtq@gmail.com

\begin{abstract}
The purpose of this study was to analyze the influence of knowledge about entrepreneurship, motivation abd independence effort seeks to performance pedagang kakilima in the area of Kotagede, Yogyakarta. The research was conducted by taking objects on pedagang kakilima in the area of Kotagede Yogyakarta. To accomplish this study, the multiple regression analysis were used to test the hypothesis put forward.

The results showed that there is significant influence entrepreneurial knowledge, motivatin and independence effort seeks to performance pedagang kakilima Kotagede area simultaneously. Partially, the motivation just trying to have significant effect, whereas knowledge of business entrepreneurship and self-reliance is not a statistically significant effect.
\end{abstract}

Keywords: entrepreneurial knowledge, motivation attempted, business independence, performance

\section{PENDAHULUAN}

Pelaku usaha kecil lebih banyak karena faktor keturunan (Zuliarni, Sri, 2013). Banyak pengusaha kecil yang merupakan generasi kedua bahkan generasi ketiga. Karena merupakan usaha keluarga maka pada umumnya keterlibatan keluarga dalam operasi sangat dominan. Ciri lain dari pelaku usaha kecil adalah pada umumnya latar belakang pendidikan mereka rendah. Meskipun demikian pada umumnya mereka memiliki ketrampilan yang terus meningkat secara bertahap karena pengalaman, namun demikian untuk meningkatkan kinerja perusahaan agar lebih baik dan agar mereka dapat mengelola usaha dengan manajemen modern perlu dilakukan upaya pembinaan dan pelatihan yang berkait pada aspek-aspek yang menjadi kebutuhan usaha diantaranya aspek permodalan, pemasaran, manajemen, sistem produksi yang meliputi teknologi, peralatan dan mutu. Di samping itu juga masalah lain seperti masalah distribusi, kewirausahaan dan peningkatan kualitas sumberdaya manusia serta pengembangan kelembagaan.

Banyak faktor yang mempengaruhi kinerja para pengusaha baik yang berasal dari faktor internal maupun eksternal. Faktor internal yaitu faktor yang bersumber dari pengusaha itu sendiri diantaranya adalah: keterbatasan kemampuan sumberdaya, latar belakang pendidikan, kemampuan teknis, permodalan, pemasaran, sistem operasi, informasi, sikap mental, etos kerja, kemandirian, percaya diri dan motivasi. Sementara dari faktor eksternal yang berasal dari luar organisasi diantaranya faktor lingkungan, peluang, persaingan dan sistem informasi global. Pada umumnya pengusaha yang kinerjanya baik adalah pengusaha yang cukup 
agresif dan atraktif, memiliki motivasi berusaha yang baik, memiliki latar belakang pengetahuan wirausaha yang tinggi dan tingkat kemandirian usaha yang baik. Sementara pengusaha yang statis dan banyak berharap mendapatkan bantuan dari pihak lain, serta tidak didorong motivasi berusaha dan pengetahuan kewirausahaan yang baik cenderung memiliki kinerja yang buruk.

Untuk menjadi pengusaha kecil yang sukses, dibutuhkan motivasi berusaha yang kuat, memiliki kemampuan, pengetahuan kewirausahaan dan harus memiliki kemandirian usaha. Hal itulah yang mendorong penulis melakukan penelitian tentang kinerja para pedagang kakilima yang merupakan salah satu pelaku usaha kecil. Lokasi yang dipilih adalah Kotagede. Adapun rumusan masalahnya adalah : apakah terdapat pengaruh pengetahuan kewirausahaan, motivasi berusaha dan kemandirian usaha terhadap kinerja para pedagang kakilima di wilayah Kotagede Yogyakarta.

Penelitian ini dilakukan dengan tujuan untuk mengidentifikasi ada tidaknya pengaruh pengetahuan kewirausahaan, motivasi berusaha dan kemandirian usaha terhadap kinerja para pedagang kakilima. Adapun manfaat yang bisa diambil dari hasil penelitian ini adalah untuk memperoleh informasi tentang kinerja dan faktor yang mempengaruhinya sehingga dapat digunakan sebagai bahan pembinaan bagi para pedagang kakilima agar mereka memiliki sikap yang baik untuk kemajuan usaha yang mereka miliki.

\section{REVIEW LITERATUR DAN HIPOTESIS}

\section{Kinerja Pedagang}

Gibson, Ivancevich dan Donelly (1997) mengatakan bahwa kinerja merupakan serangkaian kegiatan manajemen yang memberikan gambaran sejauhmana hasil yang sudah dicapai dalam melaksanakan tugas dan tanggungjawabnya dalam bentuk akuntabilitas publik baik berupa keberhasilan maupun kekurangan yang terjadi. Kinerja merupakan job performance, adanya semangat kerja dimana didalamnya termasuk beberapa nilai keberhasilan baik bagi organisasi maupun individu. Kotter dan Heskett (1997) membedakan jenis kinerja yaitu 1) kinerja ekonomis, menghasilkan etos kerja yang kuat dan berkualitas, serta 2) kinerja unggul, menghasilkan produk unggulan. Disamping itu terdapat adanya suatu kualitas kerja yang dapat diukur.Dengan demikian dapat dikatakan bahwa jenis kinerja dapat diklasifikasikan sebagai kinerja manusia, kinerja mesin dan kinerja organisasi, dimana hasil kegiatan kinerja dapat dilaksanakan secara efisien dan efektif. Sehingga akan menghasilkan etos kerja yang berkualitas serta menghasilkan produk unggulan.

Dalam kaitannya dengan penilaian kinerja, Darma (2000) mengatakan bahwa penilaian kinerja yang efektif dapat sekaligus mempengaruhi dua hal yaitu produktifitas dan kualitas kerja. Dalam rangka menilai kinerja diperlukan langkah-langkah sebagai berikut: 1) mendefinisikan pekerjaan, menilai kinerja dan memberikan umpan balik disamping adanya akuntabilitas yang jelas (Dessler, 1998).

Dari uraian diatas, dapat disimpulkan bahwa kinerja pengusaha adalah serangkaian capaian hasil kerja seorang pengusaha dalam melakukan kegiatan usaha, baik dalam pengembangan produktifitas maupun kesuksesan dalam hal pemasaran sesuai dengan wewenang dan tanggungjawabnya. Adapun indikatornya adalah: semangat kerja, kualitas kerja, produk unggulan, keberhasilan dan akuntabilitas.

\section{Pengetahuan Wirausaha}

Seseorang dikatakan mampu, karena mempunyai dua konsep dasar yaitu memiliki pengetahuan (knowledge) dan kecakapan (skill). Arti dari pengetahuan adalah pemahaman sampai pada kesadaran pikiran manusia terhadap objek tertentu, sedangkan kecakapanadalah kemampuan 
seseorang untuk dapat mempengaruhi orang lain dalam sebuah struktur organisasi yang sama. Dengan kata lain, kecakapan adalah perwujudan dari konsep pengetahuan yang dimilikinya dan merupakan tampilan proses dalam bentuk pelaksanaan (Mc Knight,2000 dalam Ranto 2007). Pengetahuan merupakan khasanah kekayaan mental yang secara langsung atau tidak langsung turut memperkaya kehidupan kita sampai adanya suatu pengertian. Dari pendapat tersebut dapat pula dipahami bahwa pengetahuan merupakan informasi segenap apa yang diketahui tentang suatu obyek tertentu. Apa yang diketahui tersebut menjadi suatu kebenaran yang diyakini. Pengetahuan didapat dari pemahaman yang berasal dari suatu pengulangan berupa pengalaman empiris atau lainnya sehingga merupakan suatu keyakinan yang akan selalu diingat.

Berkaitan dengan kewirausahaan, kata kewirausahaan diambil dari kata entrepreneurship yang artinya berusaha. Makna lebih luas dari entrepreneurship adalah suatu usaha untuk sebuah nilai kreasi melalui kesempatan bisnis, manajemen pengambilan resiko yang tepat untuk kesempatan dan melalui kemampuan komunikasi dan keahlian manajemen dalam menggerakkan manusia, keuangan dan sumberdaya materi untuk menghasilkan proyek dengan baik. Atau dengan kata lain, entrepreneurship adalah proses untuk melakukan sesuatu yang baru (kreatif) dan mengerjakan sesuatu yang berbeda (inovatif) yang bertujuan untuk meningkatkan kekayaan untuk orang dan nilai tambah terhadap masyarakat (Kao, 1995 dalam Ranto 2007).

\section{Motivasi Berusaha}

Motivasi adalah suatu konsep yang luas. Motivasi mencakup beberapa istilah lain yang menjelaskan pengaruh-pengaruh pada energi dan arah dari perilaku kita terhadap kebutuhan, minat, nilai-nilai, sikap, aspirasi dan dorongan. Motivasi bukanlah suatu perilaku, tetapi adalah pernyataan internal yang kompleks yang tidak dapat dipelajari secara langsung dan mempengaruhi perilaku (Owen, 1991 dalam Ranto 2007).

Berdasarkan teori motivasi menurut Herzberg, motivasi dibedakan menjadi motivasi intrinsik dan motivasi ekstrinsik. Motivasi intrinsik adalah keinginan dari dalam diri seseorang untuk melakukan sesuatu yang bermanfaat bagi dirinya. Sedangkan motivasi ekstrinsik adalah keinginan untuk melakukan sesuatu yang lebih dipengaruhi oleh faktorfaktor yang berasal dari luar dirinya, misalnya pujian atau bahkan hukuman. Contohnya, apabila seseorang melakukan usaha bisnis karena memiliki kemampuan, keahlian, peluang dan untuk memenuhi kebutuhan hidupnya, maka motivasi intrinsiklah yang berlaku. Sedangkan apabila seseorang berbisnis hanya karena ikutikutan temannya, maka motivasi ekstrinsiklah yang berperan.

\section{Kemandirian Usaha}

Kemandirian usaha diartikan sebagai upaya sendiri yang meliputi segala aspek kebutuhan, mampu dipenuhi sendiri tanpa harus menggantungkan pada orang lain (Ranto, 2007). Hal ini mengandung suatu maksud bahwa dengan segala usaha yang dilakukan mulai dari perencanaan, penetapan tujuan, negosiasi, memenangkan persaingan, melaksanakan pekerjaan, menciptakan ide, mencari sumbersumber dan menyelesaikan masalah usaha dapat dilakukan sendiri dengan usaha yang keras. Dengan demikian, dari usaha yang dilakukan tersebut mampu membawa keberhasilan yang memberikan kepuasan.

\section{Hubungan antara motivasi berusaha dengan kinerja pengusaha}

Motivasi berusaha adalah dorongan patriotrik pengusaha yang muncul dari dalam diri (intrinsik) dan dari luar diri (eksternal) dalam meneliti kehidupannya untuk mencari nilai- 
nilai hakiki agar cita-cita hidup berlandaskan keyakinan dan watak luhur untuk mencapai tujuan yang diharapkan.

Seorang pengusaha makin memiliki motivasi berusaha dan makin memelihara perilaku melalui tampilan etika kerjanya untuk mencapai tujuan atau sasaran yang diinginkan maka akan memberikan ekspresi positif yang berbasis pada pemikiran dan perasaannya. Dorongan dari dalam diri akan cenderung mampu mengubah dirinya dari rasa jenuh menjadi rasa tertarik yang akan memberi semangat hidupnya karena adanya energi yang mengarahkan seluruh hasrat dalam dirinya untuk menuju sasaran usaha yang telah ditetapkannya.

Terkait dengan kinerja pengusaha yaitu serangkaian nilai kerja seorang pengusaha dalam melakukan kegiatan usaha, baik dalam pengembangan produktifitas maupun kesuksesan dalam hal pemasaran, sesuai dengan wewenanng dan tanggungjawabnya. Serangkaian hasil kerja itu akan diwujudkan dalam bentuk prestasi kerja agar memperoleh kepercayaan dari koleganya. Kemudian dia akan berusaha mencari umpan balik dari hasil usaha tersebut sebagai pembuktian diri bahwa dia berani bersikap dan memiliki pendirian yang kuat. Dia juga akan berupaya selalu bersikap jujur, berlaku adil dan akan selalu berupaya membuktikan bahwa dia mampu mewujudkan sesuatu.

Perhatian pada pengembangan kerja saat ini meningkatkan kemampuan melaksanakan dengan baik danjugalebih penting memungkinkan individu memikul tanggungjawab yang lebih besar, memperluas kapasitas untuk menjalankan peranan yang lebih besar. Dan rencana kinerja ini memberikan kontribusi kepada pencapaian suatu kebijakan pengembangan terus menerus yang didasarkan pada keyakinan sehingga setiap orang mampu belajar lebih banyak dan melakukan pekerjaan dengan lebih baik. Berdasarkan pemikiran, diduga terdapat hubungan yang positif antara motivasi berusaha dengan kinerja seorang pengusaha. Dengan perkataan lain semakin kuat tingkat motivasi seorang pengusaha maka akan semakin antusias dan gigih dalam menjalankan usahanya, sebaliknya semakin lemah tingkat motivasinya akan semakin rendah pula integritasnya dalam berusaha.

\section{Hubungan antarapengetahuan kewirausahaan dengan kinerja pengusaha}

Pengetahuan kewirausahaan adalah keseluruhan apa yang diketahui tentang berbagai informasi yang diorganisir secara rasional dan logis dalam menjalankan usaha. Pengetahuan kewirausahaan tersebut meliputi aspek nilai tambah,pengambilan resiko, berbisnis dan penciptaan lapangan kerja.

Pemahaman tentang kewirausahaan akan digunakan untuk melakukan upaya pengembangan prestasi organisasi atau bisnis yang dilakukannya. Melalui ketajaman naluri bisnisnya, wirausahawan akan trampil memanfaatkan peluang dengan berbekal pengetahuan dan daya ingatnya, dean dia akan merasa percaya diri untuk mengambil resiko secara berani sehingga dia akan tampak konsisten dalam membuat berbagai keputusan.

Dengan berbekal pengetahuan, maka apa yang dilihatnya cenderung segera diterapkan secara nyata. Cara ini akan diaplikasikan melalui proses perbandingan kerja yang tepat, pengukuran pola yang tepat, sehingga akan memberikan kontribusi penampilan yang luar biasa bagi organisasinya.

Wirausahawan yang berbekal ketrampilan akan selalu mencari kesempatan dan terobosan baru untuk meningkatkan organisasinya dengan melihat kelebihan organisassi lain sebagai pola pengembangan atas segala gagasannya. Berdasar itulah maka diduga wirausahawan yang memiliki pengetahuan kewirausahaan yang baik akan menampilkan bobot kualitas kinerja yang baik pula. Dan sebaliknya, jika pengusaha tidak memiliki pengetahuan kewirausahaan yang baik, 
maka tidak akan mampu menampilkan kualitas kerja yang baik dari segi pengembangan maupun sasarannya.

\section{Hubungan antara kemandirian usaha dengan kinerja pengusaha.}

Kemandirian usaha adalah kekuatan diri dalam upaya untuk menciptakan lapangan kerja baru tanpa harus bergantung pada orang lain, mulai dari menciptakan ide, menetapkan tujuan sampai pada pencapaian kepuasan.

Kemandirian pada dasarnya adalah suatu totalitas diri yang mantap dan kuat untuk mencapai suatu tujuan atas kemampuannya sendiri. Pengusaha dikatakan mandiri apabila usahanya terus berjalan dan berkembang dari usaha sendiri yang dilakukan dengan kerja keras, ulet, jujur dan terus menerus mengembangkian usahanya melalui karya-karya sendiri. Usaha yang mandiri dan tangguh adalah yang memiliki daya saing tinggi dan memiliki kemampuan memecahkan masalah dengan bertumpu kepada kepercayaan dan kemampuan sendiri.

Wirausahawan yang memiliki kemandirian, akan selalu melakukan strategi yang tepat bagi organisasi atau rekan-rekan kerjanya. Maka seorang pengusaha yang memiliki kemandirian usaha akan selalu menjaga dirinya secara moral untuk melakukan tanggungjawabnya dengan berpegang teguh pada norma dan nilai yang dimilikinya. Demikian pula sebaliknya.

\section{Penelitian Terdahulu}

Berdasarkan penelitian yang dilakukan oleh Ranto (2007) yang berjudul Analisis Hubungan Motivasi, Pengetahuan Kewirausahaan dan Kemandirian Usaha terhadap kinerja pengusaha pada kawasan industri kecil di daerah Pulogadung, diperoleh kesimpulan bahwa terdapat hubungan jamak dan sangat signifikan. Temuan ini membuktikan bahwa terdapat hubungan positif antara motivasi berusaha, pengetahuan kewirausahaan dan kemandirian usaha secara bersama-sama dengan kinerja pengusaha industri kecil.

Berdasarkan penelitian yang dilakukan oleh Silalahi (2007) yang berjudul Pengaruh Pengetahuan Kewirausahaan, Motivasi Berprestasi dan Kemandirian Pribadi terhadap Perilaku Kewirausahaan (Studi Kasus di Warnet) diperoleh hasilbahwapengetahuankewirausahaan dan kemandirian berpengaruh signifikan terhadap perilaku kewirausahaan pada para pemilik usaha. Hanya motif berprestasi yang tidak berpengaruh terhadap perilaku kewirausahaan.

Penelitian yang dikakukan oleh Amelia (2009) dengan judul Pengaruh Pengetahuan Kewirausahaan dan Kemandirian Pribadi terhadap Kinerja Usaha pada Pedagang Pakaian Pajak Sore diperoleh hasil bahwa pengetahuan kewirausahaan dan kemandirian pribadi berpengaruh positif dan signifikan terhadap kinerja.

\section{Hipotesis}

Berdasarkan kajian pustaka dan kajian penelitian terdahulu, maka peneliti mengajukan hipotesis dalam penelitian ini bahwa: terdapat pengaruh pengetahuan kewirausahaan, motivasi berusaha dan kemandirian usaha terhadap kinerja para pedagang kakilima, baik secara parsial maupun secara serentak.

\section{METODE PENELITIAN}

\section{Jenis data dan cara pengumpulannya}

Data yang digunakan dalam analisis penelitian ini hanya data primer saja. Data primer digunakan sebagai bahan utama untuk memperoleh data variabel-variabel penelitian, yaitu tentang pengetahuan kewirausahaan, motivasi berusaha, kemandirian usaha terhadap kinerja para pedagang. Pengumpulan data primer dilakukan dengan cara memberikan daftar pertanyaan (kuesioner) kepada responden yang sudah ditentukan karakteristiknya. 


\section{Populasi dan sampel}

Populasi adalah wilayah generalisasi yang terdiri atas obyek/subyek yang mempunyai kuantitas dan karakteristik tertentu yang ditetapkan oleh peneliti untuk dipelajari dan kemudian ditarik kesimpulannya (Sugiyono, 1997). Dari sebuah populasi, dengan seluruh kumpulan elemen yang ada didalamnya dapat kita gunakan untuk membuat beberapa kesimpulan (Cooper dan Emory, 1995). Dalam penelitian ini, peneliti membatasi populasinya adalah seluruh pedagang kakilima yang berada di wilayah sekitar Pasar Legi Kotagede Yogyakarta.

Pengambilan sampel dalam penelitian ini berdasarkan teknik convenience sampling, dengan alasan agar peneliti memiliki kebebasan untuk memilih calon responden yang mudah ditemui untuk dimintai informasi, bila dipandang orang yang kebetulan ditemui itu cocok sebagai sumber data. Karena jumlah populasi yang tidak terbatas, peneliti menentukan sampel sebanyak 100 responden yang dianggap bisa mewakili seluruh populasi yang ada.

\section{Pengukuran Variabel}

Ciri-ciri pengukuran yang baik adalah bahwa alat pengukurnya harus merupakan indikator yang tepat mengenai apa yang menjadi kepentingan kita untuk diukur. Disamping itu, alat tersebut harus mudah dan efisien untuk dipakai (Cooper dan Emory 1995.

Penelitian ini menggunakan kuesioner sebagai alat pengumpulan data yang utama. Untuk kepentingan dalam penelitian ini, peneliti menggunakan kuesioner yang telah digunakan oleh beberapa peneliti sebelumnya dengan sedikit penyesuaian.

\section{Uji Validitas dan Reliabilitas}

Untuk mendapatkan data yang berkualitas, maka kuesioner penelitian yang akan digunakan harus diuji validitas dan reliabilitasnya terlebih dahulu. Hal ini dilakukan agar dapat : a. menghindari pernyataan-pernyataan yang kurang jelas, sehingga dapat menyulitkan responden pada saat menjawab.

b. menghindari kata-kata yang bermakna ganda.

c. mengetahui waktu yang diperlukan untuk mengisi kuesioner secara lengkap.

d. memberi keyakinan bahwa kuesioner yang dikirim kepada responden sudah tepat mengukur konsep yang dimaksud.

Uji validitas digunakan untuk mengetahui sejauhmana instrumen (pernyataan-pernyataan dalam kuesioner) dapat digunakan untuk mengukur konsep yang dimaksud (Sugiyono, 1997; Sekaran, 1992). Instrumen penelitian dapat dikembangkan menurut teori-teori yang relevan. Apabila bangunan teorinya sudah benar, maka hasil pengukuran dengan instrumen yang berbasis pada teori itu sudah dipandang sebagai hasil yang valid (Hadi, 1991). Sedangkan uji reliabilitas dilakukan untuk mengetahui sejauhmana hasil suatu pengukuran dapat dipercaya, dengan kata lain untuk menguji kestabilan dan konsistensi instrumen dalam mengukur konsep. Untuk menguji reliabilitas instrumen penelitian ini digunakan teknik Cronbach Alpha.

Uji normalitas perlu dilakukan untuk menentukan alat statistik yang akan dipergunakan. Apabila data yang diperoleh itu terdistribusi secara normal, maka pengujian hipotesis dapat dilakukan dengan alat statistik parametrik. Tetapi apabila data yang diperoleh tidak terdistribusi secara normal, maka pengujian hipotesis dilakukan dengan alat statistik non parametrik. Untuk pengujian normalitas data, digunakan uji Kolmogorov-Smirnov (K-S), apabila signifikansinya lebih besar dari 0,05 berarti data tersebut terdistribusi secara normal.

\section{Alat Analisis Data}

Untuk melakukan pembuktian hipotesis, penelitian ini menggunakan metode analisis statistik. Teknik statistik yang akan digunakan 
untuk pengujian tergantung pada interaksi antara dua hal yaitu macam data yang akan dianalisis dan bentuk hipotesisnya (Sugiyono, 1997). Apabila jenis datanya interval atau rasio dan datanya berdistribusi normal, maka dapat dipergunakan alat statistik parametrik, tetapi apabila jenis datanya nominal atau ordinal dan datanya tidak berdistribusi normal, maka akan dipergunakan alat statistik non parametrik. Apabila menggunakan statistik parametrik, maka untuk menguji hipotesis diatas akan digunakan alat uji regresi.

\section{Hasil Uji Kualitas Data}

\section{Uji Validitas}

Uji validitas digunakan untuk mengetahui sejauhmana instrumen (pernyataan-pernyataan dalam kuesioner) dapat digunakan untuk mengukur konsep yang dimaksud (Sugiyono, 1997; Sekaran, 1992). Instrumen penelitian dapat dikembangkan menurut teori-teori yang relevan. Apabila bangunan teorinya sudah benar, maka hasil pengukuran dengan instrumen yang berbasis pada teori itu sudah dipandang sebagai hasil yang valid (Hadi, 1991). Dalam penelitian ini butir pernyataan dinyatakan valid bila angka korelasi Product Moment Pearson dinyatakan signifikan. Adapun hasil perhitungannya dapat dilihat pada table berikut:

Tabel. 1

Hasil Uji Validitas Variabel Kinerja

\begin{tabular}{|c|c|c|c|}
\hline $\begin{array}{c}\text { Item } \\
\text { Pernyataan }\end{array}$ & $\begin{array}{c}\text { Pearson } \\
\text { Correlation }\end{array}$ & Sig & Ket \\
\hline 1 & 0,683 & 0,000 & Valid \\
\hline 2 & 0,698 & 0,000 & Valid \\
\hline 3 & 0,663 & 0,000 & Valid \\
\hline 4 & 0,630 & 0,000 & Valid \\
\hline 5 & 0,697 & 0,000 & Valid \\
\hline
\end{tabular}

Sumber: data diolah (2014)

Berdasarkan hasil uji validitas variable kinerja seperti terlihat pada table 1 diatas maka semua item pernyataan tersebut dinyatakan valid.
Tabel 2

Hasil Uji Validitas Variabel Motivasi Berusaha

\begin{tabular}{|c|c|c|c|}
\hline $\begin{array}{c}\text { Item } \\
\text { Pernyataan }\end{array}$ & $\begin{array}{c}\text { Pearson } \\
\text { Correlation }\end{array}$ & Sig & Ket \\
\hline 1 & 0,873 & 0,000 & Valid \\
\hline 2 & 0,762 & 0,000 & Valid \\
\hline 3 & 0,778 & 0,000 & Valid \\
\hline 4 & 0,802 & 0,000 & Valid \\
\hline 5 & 0,822 & 0,000 & Valid \\
\hline
\end{tabular}

Sumber: data diolah (2014)

Berdasarkan hasil uji validitas variable motivasi berusaha seperti terlihat pada table 2 diatas maka semua item pernyataan dinyatakan valid.

Tabel 3

\section{Hasil Uji Validitas Variabel Pengetahuan Kewirausahaan}

\begin{tabular}{|c|c|c|c|}
\hline $\begin{array}{c}\text { Item } \\
\text { Pernyataan }\end{array}$ & $\begin{array}{c}\text { Pearson } \\
\text { Correlation }\end{array}$ & Sig & Ket \\
\hline 1 & 0,676 & 0,000 & Valid \\
\hline 2 & 0,757 & 0,000 & Valid \\
\hline 3 & 0,595 & 0,000 & Valid \\
\hline 4 & 0,728 & 0,000 & Valid \\
\hline 5 & 0,755 & 0,000 & Valid \\
\hline
\end{tabular}

Sumber: data diolah (2014)

Berdasarkan hasil uji validitas variable pengetahuan kewirausahaan seperti terlihat pada table 4.3 diatas maka semua item pernyataan dinyatakan valid.

Tabel 4

\section{Hasil Uji Validitas Variabel Kemandirian Usaha}

\begin{tabular}{|c|c|c|c|}
\hline $\begin{array}{c}\text { Item } \\
\text { Pernyataan }\end{array}$ & $\begin{array}{c}\text { Pearson } \\
\text { Correlation }\end{array}$ & Sig & Ket \\
\hline 1 & 0,788 & 0,000 & Valid \\
\hline 2 & 0,748 & 0,000 & Valid \\
\hline 3 & 0,597 & 0,000 & Valid \\
\hline 4 & 0,406 & 0,000 & Valid \\
\hline
\end{tabular}

Sumber: data diolah (2014) 
Berdasarkan hasil uji validitas variabel kemandirian usaha seperti terlihat pada tabel 4.4 diatas maka semua item pernyataan dinyatakan valid.

\section{Uji Reliabilitas}

Uji reliabilitas dilakukan untuk mengetahui sejauhmana hasil suatu pengukuran dapat dipercaya, dengan kata lain untuk menguji kestabilan dan konsistensi instrumen dalam mengukur konsep. Untuk menguji reliabilitas instrumen penelitian ini digunakan teknik Cronbach Alpha. Jika nilai Cronbach Alpha diatas 0,60 maka kuesioner dikatakan konsisten atau reliable (Ghozali, 2002). Berdasarkan perhitungan dengan program SPSS, diperoleh nilai Cronbach Alpha sebesar 0,695. Oleh karena itu, karena nilai alpha diatas 0,60 maka dianggap reliable. Dengan demikian berdasar uji validitas dan reliabilitas yang telah dilakukan, maka itemitem pernyataan dalam kuesioner yang akan digunakan dinyatakan konsisten atau reliable untuk mencari data.

\section{HASIL PENELITIAN DAN PEMBAHASAN}

\section{Deskripsi Responden}

Untuk keperluan penelitian ini, peneliti mengedarkan kuesioner guna memperoleh data penelitian kepada para pedagang kakilima yang ada di wilayah sekitar Pasar Legi Kotagede Yogyakarta. Seluruh kuesioner yang diedarkan sebanyak 100 eksemplar, dari jumlah tersebut yang kembali sebanyak 95 eksemplar. Setelah diteliti, kesemuanya layak digunakan sebagai data penelitian. Mengenai profil responden dalam penelitian ini dapat dilihat dari berbagai aspek demografis seperti terlihat dalam tabel-tabel sebagai berikut:
Tabel 5

Profil Responden Berdasar Jenis Kelamin

\begin{tabular}{|c|c|c|}
\hline Jenis Kelamin & Jumlah & Persentase \\
\hline Pria & 64 orang & 67,4 \\
Wanita & 31 orang & 32,6 \\
\hline Jumlah & 95 orang & 100 \\
\hline
\end{tabular}

Sumber: data diolah (2014)

Responden yang terlibat dalam penelitian ini kebetulan jumlah pria lebih banyak daripada wanita yaitu 64 orang atau $67,4 \%$ dan yang berjenis kelamin wanita terdapat 31 orang atau 32,6\% saja. Hal ini terjadi hanya secara kebetulan saja yang peneliti temui ketika penyebaran kuesioner. Tidak ada kecenderungan tertentu untuk memilih salah satu lebih banyak.

Tabel 6

Profil Responden Berdasar Usia

\begin{tabular}{|c|c|c|}
\hline Golongan Usia & Jumlah & Persentase \\
\hline$\leq 30$ tahun & 16 orang & 16,8 \\
$31-40$ tahun & 33 orang & 34,7 \\
$41-50$ tahun & 27 orang & 28,4 \\
$51-60$ tahun & 18 orang & 18,9 \\
$>60$ tahun & 1 orang & 1,2 \\
\hline Jumlah & 95 orang & 100 \\
\hline
\end{tabular}

Sumber: data diolah (2014)

Berdasarkan tabel 6 tersebut, terlihat bahwa responden yang berpartisipasi dalam penelitian ini sebagian besar adalah berusia antara 31 - 40 tahun, yaitu sebanyak 33 orang atau $34,7 \%$. Sedangkan responden yang berusia antara 41 sampai 50 tahun berjumlah 27 orang atau $28,4 \%$. Diikuti responden yang berusia antara 51 hingga 60 tahun sebanyak 18 orang $(18,9 \%)$, kemudian ada 16 orang (16,8\%) yang berusia kurang dari 30 tahun. Dan terakhir sebanyak 1 orang berusia lebih dari 60 tahun. 
Tabel 4

Profil Responden Berdasar Pendidikan

\begin{tabular}{|l|c|c|}
\hline Jenjang Pendidikan & Jumlah & Persentase \\
\hline Tidak Sekolah & 3 orang & 3,2 \\
SD & 15 orang & 15,8 \\
SMP & 14 orang & 14,7 \\
SMA/SMK & 60 orang & 63,2 \\
Diploma & 2 orang & 2,1 \\
Sarjana & 1 orang & 1,1 \\
\hline \multicolumn{1}{|c|}{ Jumlah } & 95 orang & 100 \\
\hline
\end{tabular}

Sumber: data diolah (2014)

Sebagian besar responden yang berpartisipasi dalam penelitian ini adalah berpendidikan SMA sebanyak 60 orang $(63,2 \%)$ diikuti responden yang berpendidikan Sekolah Dasar sebanyak 15 orang atau $15,8 \%$ dan terdapat 14 orang $(14,7 \%)$ yang berpendidikan SMP, yang tidak bersekolah sebanyak 3 orang $(3,2 \%)$, berpendidikan Diploma 2 orang $(2,1 \%)$ dan satu orang $(1,1 \%)$ responden memiliki tingkat pendidikan terakhir Sarjana.

\section{Tabel 8}

\section{Profil Responden Berdasar Lama Berusaha} sebagai Pedagang

\begin{tabular}{|l|r|c|}
\hline \multicolumn{1}{|c|}{ Lama Berusaha } & Jumlah & Persentase \\
\hline$\leq 5$ tahun & 49 orang & 51,5 \\
$6-10$ tahun & 30 orang & 31,5 \\
$11-20$ tahun & 13 orang & 13,6 \\
$21-30$ tahun & 1 orang & 1,3 \\
$>30$ tahun & 2 orang & 2,1 \\
\hline \multicolumn{1}{|c|}{ Jumlah } & 95 orang & 100 \\
\hline
\end{tabular}

Sumber: data diolah (2014)

Responden dalam penelitian ini sebagian besar memiliki masa kerja (lama berusaha sebagai pedagang) kurang dari 5 tahun yaitu sebanyak 49 orang atau $51,5 \%$, sedangkan yang memiliki lama usaha antara 6 hingga 10 tahun sebanyak 30 orang atau $31,5 \%$ dan 13 orang atau $13,6 \%$ yang memiliki lama usaha antara 11 sampai 20 tahun. Terdapat dua orang dengan lama usaha lebih dari
30 tahun dan hanya satu orang dengan lama usaha 21 sampai 30 tahun.

\section{Analisis Data}

Sebagaimana telah dikemukakan oleh Sugiyono (1997) bahwa teknik statistik yang akan digunakan dalam pengujian hipotesis tergantung pada interaksi antara dua hal yaitu macam data yang akan dianalisis dan bentuk hipotesisnya. Dalam penelitian ini, instrumennya menggunakan skala Likert, sehingga data yang diperoleh adalah data interval dan diambil dari populasi yang berdistribusi normal. Hal ini menunjukkan bahwa pengujian hipotesis dapat menggunakan alat statistik parametrik. Maka untuk pengujian hipotesis dalam penelitian ini digunakan alat uji regresi linier untuk menguji hipotesis.

Untuk melakukan analisis dengan alat tersebut, bisa menggunakan salah satu kriteria di bawah ini atau keduanya sekaligus agar lebih kuat.

1. Apabila t hitung (positif) lebih besar atau sama dengan $t$ tabel (positif) atau apabila $t$ hitung (negatif) lebih kecil atau sama dengan $t$ tabel (negatif) maka $\mathrm{H} 0$ ditolak (Ha diterima), dan apabila t hitung (positif) lebih kecil dari $\mathrm{t}$ tabel (positif) atau $\mathrm{t}$ hitung (negatif) lebih besar dari t tabel (negatif) maka H0 diterima (Hadi, 1991).

2. Apabila signifikansi (p-value) $>0,05$ maka H0 diterima (Ha ditolak), jika signifikansi (p-value) < 0,05 maka H0 ditolak dan Ha diterima. Tingkat signifikansi yang digunakan dalam penelitian ini ditetapkan sebesar 5\%.

\section{Pengujian Hipotesis}

Hipotesis dalam penelitian ini menyatakan bahwa "terdapat pengaruh pengetahuan kewirausahaan, motivasi berusaha, kemandirian usaha terhadap kinerja para pedagang kakilima, baik secara parsial maupun secara serentak. 
Setelah dilakukan analisis regresi dengan program SPSS dihasilkan output seperti dalam tabel sebagai berikut:

\section{Tabel 9}

Hasil Analsis Regresi

\begin{tabular}{|c|c|c|c|c|c|c|}
\hline \multicolumn{2}{|c|}{ Model } & \multirow{2}{*}{$\begin{array}{r}\begin{array}{r}\text { Sum of } \\
\text { Squares }\end{array} \\
1,524\end{array}$} & \multirow{2}{*}{$\frac{\mathrm{df}}{3}$} & \multirow{2}{*}{$\begin{array}{r}\begin{array}{l}\text { Mean } \\
\text { Square }\end{array} \\
, 508\end{array}$} & \multirow{2}{*}{$\frac{F}{5,058}$} & \multirow{2}{*}{$\begin{array}{l}\text { Sig. } \\
, 003(a)\end{array}$} \\
\hline 1 & Regression & & & & & \\
\hline & Residual & 9,141 & 91 &, 100 & & \\
\hline & Total & 10,665 & 94 & & & \\
\hline
\end{tabular}

a Predictors: (Constant), K, MB, PK

b Dependent Variable: Krj

\section{Coefficients(a)}

\begin{tabular}{|c|c|c|c|c|c|c|}
\hline \multirow{2}{*}{\multicolumn{2}{|c|}{ Model }} & \multicolumn{2}{|c|}{$\begin{array}{l}\text { Unstandardized } \\
\text { Coefficients }\end{array}$} & \multirow{2}{*}{$\begin{array}{c}\begin{array}{c}\text { Standardized } \\
\text { Coefficients }\end{array} \\
\text { Beta }\end{array}$} & \multirow[t]{2}{*}{$\mathrm{T}$} & \multirow[t]{2}{*}{ Sig. } \\
\hline & & B & $\begin{array}{l}\text { Std. } \\
\text { Error }\end{array}$ & & & \\
\hline \multirow[t]{4}{*}{1} & (Constant) & 2,863 & , 460 & & 6,225 & ,000 \\
\hline & MB & ,262 & 081 & ,340 & 3,240 &, 002 \\
\hline & PK & 030 & 091 & 034 & ,328 & ,744 \\
\hline & $\mathrm{K}$ & 059 & ,062 & ,092 & 937 & 351 \\
\hline
\end{tabular}

a Dependent Variable: Krj

Berdasarkan tabel di atas, hasil analisis regresi parsial yang dilakukan diperoleh nilai $t$ hitung untuk variabel Motivasi Berusaha (MB) sebesar 3,240 dan signifikansi 0,002. Variabel Pengetahuan Kewirausahaan (PK) thitung sebesar 0,328 dan signifikansi 0,744. Sedangkan untuk t hitung variabel Kemandirian (K) sebesar 0,937 dan signifikansi 0,351. Berdasarkan kriteria yang sudah ada, angka tersebut menunjukkan bahwa Ha diterima untuk Motivasi Berusaha (MB), sedangkan untuk Pengetahuan Kewirausahaan (PK) dan Kemandirian Usaha (K) Ha ditolak. Dengan demikian dapat dinyatakan bahwa ada pengaruh variabel Motivasi Berusaha terhadap kinerja pedagang kakilima di wilayah Kotagede dan tidak terdapat pengaruh variabel Pengetahuan Kewirausahaan dan Kemandirian usaha terhadap kinerja pedagang kakilima di wilayah Kotagede secara parsial.

Untuk menguji ada tidaknya pengaruh ketiga variabel yaitu Motivasi Berusaha,
Pengetahuan Kewirausahaan dan Kemandirian terhadap kinerja pedagang kakilima wilayah Kotagede secara serentak, dapat dilihat dari hasil uji regresi serentak yang menghasilkan nilai F hitung sebesar 5,058 dan nilai signifikansi p-value 0,003. Dari angka tersebut dapat diartikan bahwa variabel Motivasi Berusaha, Pengetahuan Kewirausahaan dan Kemandirian usaha secara serentak berpengaruh sangat signifikan terhadap kinerja pedagang kakilima wilayah Kotagede Yogyakarta.

Berdasarkan hasil analisis data di atas, dapat dipahami bahwa dalam berbisnis, para pedagang kakilima dalam penelitian ini memang membutuhkan ketiga variable sekaligus yaitu motivasi berusaha, pengetahuan kewirausahaan dan kemandirian usaha. Apabila terpisah, maka hanya variable motivasi berusaha saja yang berpengaruh terhadap kinerja pedagang, sedangkan pengetahuan kewirausahaan dan kemandirian usaha tidak berpengaruh langsung terhadap kinerja pedagang.

\section{KESIMPULAN DAN SARAN}

\section{Kesimpulan}

Berdasarkan hasil uji hipotesis dan pembahasan pada bab sebelumnya, maka penelitian ini dapat disambil kesimpulan sebagai berikut: Terdapat pengaruh variabel motivasi berusaha terhadap kinerja pedagang kaki lima, tetapi tidak ada pengaruh variable pengetahuan kewirausahaan dan kemandirian usaha terhadap kinerja pedagang kaki lima secara parsial. Secara serentak, ketiga variabel yaitu motivasi berusaha, pengetahuan kewirausahaan dan kemandirian usaha berpengaruh terhadap kinerja pedagang kakilima dengan sangat signifikan.

\section{Saran}

Bagi Pengusaha: perlu menambah pengetahuan kewirausahaan baik melalui pendidikan maupun pelatihan serta membaca 
literature atau biografi para pengusaha yang telah sukses sebelumnya sebagai bekal untuk masa depan yang lebih baik.

Bagi peneliti berikutnya: perlu melakukan penelitian lebih lanjut untuk mengungkap variable-variabel lain yang dapat mempengaruhi kinerja pedagang kakilima.

Peneliti menyadari sepenuhnya bahwa dalam penelitian ini memiliki keterbatasan dalam dukungan teori dan hasil kajian penelitian sebelumnya, karena penelitian dalam bidang ini yang berkaitan dengan kinerja pedagang masih sangat terbatas, sehingga pembuktian hasil penelitian dengan teori pendukungnya relatif juga terbatas.

Penelitian ini hanya menggunakan 95 responden pedagang kakilima di wilayah sekitar pasar Legi Kotagede Yogyakarta saja sehingga hasil penelitian ini mungkin belum dapat digeneralisir. Mengenai responden, ada dugaan bahwa beberapa diantara mereka tidak memberikan jawaban terhadap kuesioner yang diajukan secara obyektif. Hal ini dimungkinkan karena beberapa hal antara lain keengganan responden untuk mengisi kuesioner, karena kuesioner dianggap mengganggu pekerjaannya, sehingga mereka menjawab sekenanya.

\section{DAFTAR PUSTAKA}

Cooper D.R dan Emory CW (1996) Metode Penelitian Bisnis. Alih bahasa: Ellen G dan Imam N. Penerbit Erlangga Jakarta.

Darma, Agus. (2000) Manajemen Supervisi. Jakarta: Raja Grafindo Persada.
Dessler, Gary. (1998) Manajemen Sumberdaya Manusia Edisi Bahasa Indonesia Jilid 2 alih bahasa Benjamin Molan. Jakarta: Prenhallindo.

Ghozali (2002) Aplikasi Analisis Multivariate dengan Program SPSS. Badan Penerbit Universitas Diponegoro Semarang.

Gibson, Ivancevich and Donelly (1997) Organization: behavior, structure, process. USA: Richard D. Irwin, a Times Mirror Higher Educations.

Hadi, Sutrisno (2002). Metodologi Research. Yogyakarta: Andi Offset.

Kotter, John P.and James L. Heskett (1997) Dampak Budaya Perusahaan terhadap Kinerja. Alih bahasa Benjamin Molan. Jakarta: PT Prenhallindo Simon and Scuter (Asia).

Ranto, Basuki (2007) Korelasi antara Motivasi, Knowledge of Entrepreneurship dan Independensi dan the Entrepreneur's Performance pada kawasan industri kecil, Usahawan No.10 TH XXXVI Oktober, Jakarta.

Sekaran, Uma (1992) Research Methods for Business. John Willey and Sons.

Sugiyono, 1999, Statistik untuk Penelitian, Alfabeta, Bandung.

http://repository.unri.ac.id, 2013, Karakteristik Pengusaha dan Karyawan Industri Kreatif di Pekanbaru, Univ Riau. 